\title{
Proce edings of
}

\section{the United States}

Nation a l M u s u m

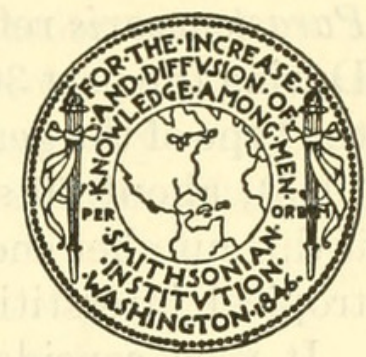

SMITHSONIAN INSTITUTION • WASHINGTON, D.C.

Number 3458

\section{TWO NEW SPECIES OF PARASTENOCARIS (COPEPODA:} HARPACTICOIDEA) FROM SANTA CATARINA, BRAZIL

\section{By Hans Jakobi and Jayme de Loyola e Silva}

\section{Introduction}

Although subterranean waters are widespread, the study of their inhabitants (troglobiotic fauna) has been carried out only to a limited extent because of sampling difficulties. Collections from holes, caves, wells, and aqueducts give an indirect and incomplete view of the subterranean microfauna. Recent studies have shown that for an adequate picture we must investigate directly the less accessible subterranean interstitial systems ("Lückensysteme") formed by earth clefts, cracks, fissures, and sand gaps (Jakobi, 1951).

As a result of selection, troglobiotic species are highly modified and adapted to their environment. Such characters as small size, slender body, reduced limbs, and specialized modes of feeding and reproduction fit them for existence in the limited spaces of the interstitial habitat. Two groups with great plasticity, the Nematoda and the Copepoda, contain the greatest number of troglobiotic species.

Among the subterranean Copepoda, the highly specialized Parastenocaridae are of special interest because of their geographical distribution, their division into numerous species, the high degree of 
sexual dimorphism, and their mode of reproduction (the eggs are deposited freely). As in the case of the crustaceans Bathynella, Niphargus, and Microparasellus, and the polychaete Troglochaetus, Parastenocaris reflects the amount of research on subterranean waters. During the past 30 years this research has greatly increased. Although the type of the genus, P. brevipes, was not described until 1913 (Kessler, 1913), about 70 species are now known. It would not be surprising if this number should eventually exceed 100, inasmuch as the study of tropical interstitial biotopes is in its infancy.

It is of considerable interest that until about 1950, tropical Parastenocaridae were found only in water in the interstices of plants, whereas in Europe the genus Parastenocaris occurs almost exclusively in subterranean biotopes. Of the European species, only P. brevipes is known from both surface and subterranean situations. In recent years, however, several new subterranean species of Parastenocaris have been discovered from Africa and South America (Chappuis, 1952; 1954a; Noodt, 1955).

The following abbreviations are used in the descriptions and illustrations that follow:

\begin{tabular}{ll|ll} 
A.1 & Antennule & P.1-P.5 & Thoracic legs \\
A.2 & Antenna & Exp. & Exopodite \\
Md & Mandible & Enp. & Endopodite \\
Mx & Maxillule & Benp. & Base-endopodite \\
Mxl & Maxilla & Fu & Furca \\
Mxp & Maxilliped & &
\end{tabular}

We wish to acknowledge the aid received from Conselho Nacional de Pesquisas, Rio de Janeiro.

Genus Parastenocaris Kessler, 1913

\section{Parastenocaris brasilibathynellae, new species}

Figure 1

Female: Body cylindrical, cephalothorax considerably larger than any of the following segments, twice as long as third thoracic segment; operculum concave centrally, well chitinized, without ornamentation. Size varies according to method of fixation, normally about 10 times longer than wide. Body segments without ornamentation or other differentiations. Rostrum lacking. Furcal branches about 3 times longer than wide; the terminal bristles reduced to spines (sexual dimorphism), as in Parastenocaris hexacantha Kiefer 1936, oval as seen from side, in contradistinction to male. Furca of the same length in both sexes, always a little shorter than the last abdominal segment (for details, consult figures). Mandibula a very small chewing plate, divided. Maxillule small and with relatively strong bristles. Maxilliped easily demonstrable, prehensile. 
A.1 6-jointed, true second article absent, fused with first. First article forms a very strong trunk bearing the rest of the relatively small antennula. First article as long as the following three combined, and also as long as the furcal branches. Sensory setae on the third and sixth articles, like Parastenocaris bidens Noodt. The three bristles, situated at the inside of the first article, are very characteristic. A.2 with relatively great allobase, much smaller Enp. and

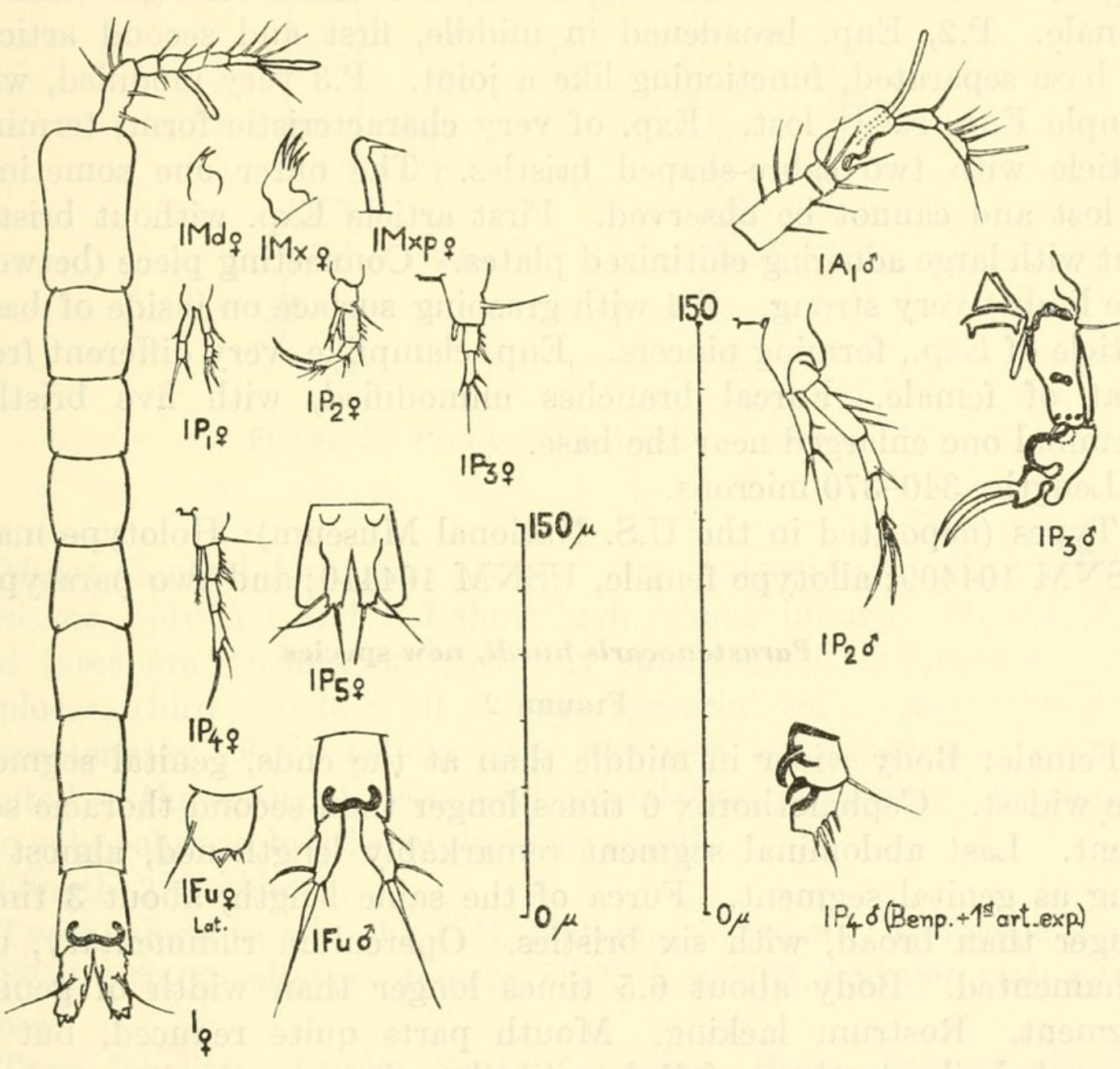

Figure 1.-Parastenocaris brasilibathynellae, new species.

very vestigial Exp. bearing a small bristle; sometimes the Exp. cannot be found in spite of all care during preparation.

P.1 Exp. 3-jointed, Enp. 2-jointed, with two bristles of different lengths. Enp. a little longer than Exp. Length of second article of Enp. about half that of first, with small distal inner marginal bristle. Exp. with three well-developed and two rudimentary bristles apically, second article without bristles. P.2-P.4 each with 1-jointed Enp., varying considerably in structure. Enp. P.2, with two terminal bristles, but only one on inner margin. Enp. P.3 lacking bristles. Enp. P.4 with one terminal and two smaller lateral bristles. Enp. P.4 about 8 times longer than wide, easily lost. P.5 spatuliform, about 
2.5 times longer than wide, with three terminal bristles in a characteristic position; middle bristle always curves outward. Situated behind the limb base are two symmetrical lunate disks, which can be seen very well after treatment with $\mathrm{KOH}$ and crushing.

Length, 300-340 microns.

Male: Basic form like that of female but with great sexual modification on A.1, P.2-4, and the furca. A.1 a very strong grasping: organ, third and fourth articles fused, 2-3 times stronger than in female. P.2, Enp. broadened in middle, first and second articles of base separated, functioning like a joint. P.3 very modified, with simple Enp. easily lost. Exp. of very characteristic form; terminal article with two sabre-shaped bristles. The outer one sometimes is lost and cannot be observed. First article Exp. without bristles but with large adhering chitinized plates. Connecting piece (between the limbs) very strong. P.4 with grasping surface on inside of basal article of Exp., forming pincers. Enp. clamplike, very different from that of female. Furcal branches unmodified, with five bristles, terminal one enlarged near the base.

Length: $340-370$ microns.

Types (deposited in the U.S. National Museum): Holotype male, USNM 104409; allotype female, USNM 104410; and two paratypes.

\section{Parastenocaris hurdi, new species}

Figure 2

Female: Body wider in middle than at the ends, genital segment the widest. Cephalothorax 6 times longer than second thoracic segment. Last abdominal segment remarkably lengthened, almost as long as genital segment. Furca of the same length, about 3 times longer than broad, with six bristles. Operculum rudimentary, unornamented. Body about 6.5 times longer than width of genital segment. Rostrum lacking. Mouth parts quite reduced, but in general similar to those of $P$. brasilibathynellae.

A.1 6-jointed; first article forms a strong trunk; second article with three very characteristic bristles on inner margin.

A.2 with a strong allobase, Enp. small. Exp. or an equivalent bristle apparently absent, but a large sensory seta is present on the base. P.1 Exp. 3-jointed, the middle article without a bristle. Terminal article with three bristles of differing length. Enp. 2jointed, second article with two terminal bristles, first article without a bristle; the two articles subequal. P.2-P.4 with 1-jointed Enps. Enp. P.2 with two terminal bristles, those of P.3 and P.4 with one terminal bristle. Enp. P.2 easily broken. P.5 about 2 times longer than wide, with four bristles.

Length, 220 microns. 


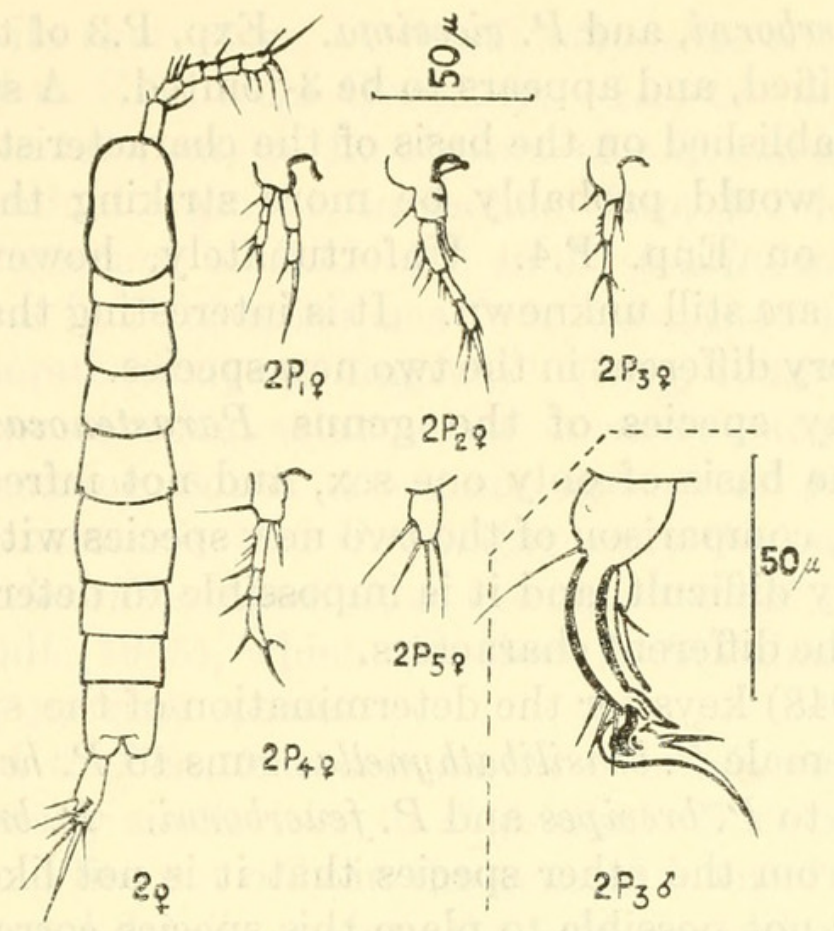

Figure 2.-Parastenocaris hurdi, new species.

Male: General form like female. In contrast with $P$. brasilibathynellae, only A.1 and P.3 show high sexual dimorphism; P.2, P.4, and furca are without or with only small sexual differences. A.1 haplocer, third article with a large sensorial seta. Enp. P.3 very characteristic. First article Exp. strongly chitinized and curved, jointed to the second by a special articulation, second article bearing two sabre-shaped bristles of different length.

Length, 220 microns.

Types (deposited in the U.S. National Museum): Holotype male, USNM 104402; allotype female, USNM 104403, and two male paratypes.

Type locality. Lagôa, Santa Catarina, Brazil (cf. "Ecology," p. 395).

Named hurdi in honor of Dr. Paul Hurd, Department of Entomology, University of California, Berkeley, Calif.

\section{Discussion}

With regard to Parastenocaris brasilibathynellae, it is remarkable that A.1 has only six, rather than the usual seven joints, and that the rostrum is lacking. The terminal article of Exp. P.1 has five bristles, as in $P$. chelifer Delachaux from Surinam. The first article of Enp. P.1 of $P$. brasilibathynellae has one inner marginal bristle, which is absent in many species, e.g., $P$. hurdi, $P$. brevipes, $P$. chelifer, $P$. 
fonticola, P. feuerborni, and P. vicesima. Exp. P.3 of the male is very strong and modified, and appears to be 3 -jointed. A subgenus should probably be established on the basis of the characteristic form of Exp. P.3 male; this would probably be more striking than the present division based on Enp. P.4. Unfortunately, however, the males of many species are still unknown. It is interesting that the structure of Exp. P.4 is very different in the two new species.

Because many species of the genus Parastenocaris have been described on the basis of only one sex, and not infrequently from a single specimen, comparison of the two new species with those already described is very difficult, and it is impossible to determine the range of variation in the different characters.

In Lang's (1948) keys for the determination of the species of Parastenocaris, the female $P$. brasilibathynellae runs to $P$. hexacantha, while the male comes to P. brevipes and P.feuerborni. P. brasilibathynellae is so different from the other species that it is not likely to be easily confused. It is not possible to place this species correctly in the key of Chappuis (1958a), which is based on the form of Enp. P.4 male.

The sexual dimorphism of the furca is very important, and in the Harpacticoidea two types generally can be distinguished:

Mensural differences, of which examples occur in Eucanuella spinifera (female with shortened furca), Porcellidium viride (female furca much longer), Paracamptus schmeili (female furca secondarily lengthened), and Schizopera minuta (female furca secondarily lengthened).

Fundamental differences in characters, of which examples occur in Paraphyllopodopsyllus intermedius, Attheyella crassa, Huntemannia judensis, Parastenocaris trisaetosa, and P. brasilibathynellae.

In species of the latter group, it is evident that it is the female furca that is modified. In the first group of species, although the dimorphism is more superficial, it is also clear from comparison with their nearest relatives that the female furca may be associated with a function of producing sexually attractive substances. Such substances would be very important to animals living in the subterranean interstitial system.

As mentioned above, Lang's key leads to $P$. hexacantha Kiefer (1936), which has a furca similar to that of $P$. brasilibathynellae. Unfortunately, the male of $P$. hexancantha is unknown, but we may conclude that a similar sexual dimorphism exists. The A.1 of $P$. hexacantha suggests that of $P$. brasilibathynellae, especially in the position of the two sensory setae, and the thoracic limbs have some features in common. We can, perhaps, consider $P$. hexacantha, from the Rio Serido, Brazil, as the surface form of $P$. brasilibathynellae, and P. trisaetosa Chappuis (1954b) from Madagascar may be a subterranean analogue. 
In some of its characters, $P$. brasilibathynellae shows a relationship with $P$. vicesima Klie, from Germany. The two species are similar in the lack of a rostrum, in the absence of a dorsal series of spines on the last abdominal segment, in having Enp. P.1 longer than Exp., and in the structure of P.5. P.5 in P. brasilibathynellae has only three spines but in $P$. vicesima has four, though in both the "äussere und innere Borste [sind] am längsten" (Lang, 1948, p. 1236), and the outer of the two terminal setae curves strongly outward.

Of the remaining South American species of Parastenocaris ( $P$. staheli, $P$. surinamensis, and $P$. chelifer), only the last exhibits a relationship to $P$. brasilibathynellae, in the structure of P.1, P.2, and P.3. $P$. bidens Noodt (1955), which also lives in Brazilian waters, is quite different from our new species.

With regard to Parastenocaris hurdi, it is of special interest that $P$. hurdi has many similarities to $P$. fonticola Borutzky, from Russia. The relationship lies not only in the general form of the legs, but also in their structural details, mainly those of the endopodites. In both species the terminal article of Exp. P.4 is curved in the same manner. The male of $P$. fonticola is still unknown.

A comparison between $P$. brasilibathynellae and $P$. hurdi shows that the two species are quite different. This difference is especially striking in the form of P.3 male and of all the endopodites.

\section{Ecology}

The two new species described here live in association with Brasilibathynella florianopolis Jakobi (1958), which dwells in the subterranean water of the well on the property of Mr. Olympio Pires, a fisherman in the village of Lagôa on the maritime island of Santa Catarina, Brazil. The maximum number of specimens are found in the colder months, May to October. During the warmer part of the year Parastenocaris, like Brasilibathynella, appears to retreat to the more temperate inner spaces of the interstitial sand system. Physical data at the site of collection were as follows: Temperature, $22^{\circ} \mathrm{C} ; \mathrm{pH}$ 6.5 ; salinity, less than $0.2 \%$; time of pumping, 45 to 60 minutes.

It should be emphasized that the well water is fresh (cf. Jakobi, 1958 , p. $26,31-32$ ), although the brackish lagoon water (about $11 \%$ ) is only about 20 meters away. The well has existed since 1951 and is 4 meters deep. It has a Norton tube, placed in the sand of old dunes already covered by vegetation. Many years ago the site of the present well was in a lagoon connected with the sea, which is now about 1 kilometer away. This connection was eliminated by general elevation of the coast and the subsequent formation of sand dunes. Mrs. Pires stated that the well has never been dry and is locally considered as the best drinking water available. 
Collection of subterranean water samples almost everywhere will yield Parastenocaris. Even in those regions where subterranean water generally contains sparse typical faunal elements (Central America, the desert of Peru), the genus Parastenocaris always occurs with remarkable frequency (Noodt, 1959). In spite of the ideal adaptation of both Parastenocaridae and Bathynellidae for life in the interstitital subterranean system, the two families are not very frequently associated. In this connection the findings of Noll and Stammer (1953) are of great interest. These authors collected samples of subterranean water in 148 places in the Main River valley near Aschaffenburg, Germany. Bathynella natans stammeri Jakobi was found at 27 localities $(=18 \%)$ and the genus Parastenocaris at 23 places $(=15.5 \%)$, but the two genera occurred together in only 11 wells $(=7 \%)$.

Chappuis, P. A.

\section{Bibliography}

1933. Biospeologica LIX. Copépodes (première série), avec l'énumération de tous les copépodes cavernicoles connus en 1931. Arch. Zool. Expér. Gén., vol. 76, no. 1, pp. 1-56.

1952. Copépodes harpacticoides psammiques de Madagascar. Mém. Inst. Sci. Madagascar, vol. 7, no. 2, pp. 145-160.

1953. Notes sur les copépodes. 15. Un nouveau Parastenocaris de la vallée supérieure de la Weser (Hanovre). Notos Biospéologiques, vol. 8, pp. 81-83.

1954a. Harpacticoides psammiques récoltés par Cl. Delamare Deboutteville en Mediterranée. Vie et Milieu, vol. 4, no. 2, pp. 254-276.

1954b. Recherches sur la faune interstitielle des sédiments marins et d'eau douce à Madagascar. IV. Copépodes harpacticoides psammiques de Madagascar (deuxième note). Mém. Inst. Sci Madagascar, vol. 9, pp. 45-73.

1955a. Notes sur les copépodes. 18. Nouveaux harpacticoïdes des Pyrénées. 19. Harpacticoïdes cavernicoles de Grèce. 20. Copépodes harpacticoïdes des îles du Pacifique. Notes Biospéologiques, vol. 10, pp. 89-101.

1955b. Harpacticoides troglobies du Japon. Notes Biospéologiques, vol. 10, pp. 184-190.

1958a. Le genre Parastenocaris Kessler. Vie et Milieu, vol. 8, no. 4, pp. 423-432.

1958b. Biogéographie du genre Parastenocaris. Vie et Mileiu, vol. 8, no. 4, pp. 444-453.

Chappuis, P. A., and Delamare Deboutteville, Claude

1958. Recherches sur la faune interstitielle littorale du lac Érie. Vie et Milieu, vol. 8, no. 4, pp. 366-376.

HAINE. E.

1946. Die Fauna des Grundwassers von Bonn. Inaug. Diss. Bonn. 
$J_{\text {AKOBI, HANS }}$

1951. Monographie von Bathynella natans: Inaug. Diss. Erlangen.

1958. Brasilibathynella florianopolis n. gen. n. sp., ein neuer Genus der Grundwasser familie Bathynellidae (Grobben) aus der Duenenzone der Insel Santa Catarina, Suedbrasilien. Dusenia, vol. 8, no. 1 , pp. 25-36.

1959a. Contribuição para a ecologia dos Harpacticoidea (Copepoda, Crustacea). I. Adaptacão aos biótopos. Rev. Brasil. Biol., vol. 19, no. 2, pp. 134-150.

1959b. Contribuição para a ecologia dos Harpacticoidea (Copepoda, Crustacea). II. Adaptacão a salinidade e pH. Rev. Brasil. Biol., vol. 19, no. 3, pp. 271-286.

Kessler, E.

1913. Parastenocaris brevipes nov. gen. et nov. sp., ein neuer Süsswasserharpacticide. Zool. Anz., vol. 42, no. 11, pp. 514-520.

KIEFER, Friedrich

1936. Eine neue Parastenocaris-Art (Crustacea Copepoda) aus Brasilien. Zool. Anz., vol. 116, no. 5/6, pp. 142-144.

LANG, KARL

1948. Monographie der Harpacticiden, vol. 2, pp. 899-1682. Lund.

Noll, W. and Stammer, H. J.

1953. Die Grundwasserfauna des Untermaingebietes. Mittel. Nat. Mus. Aschaffenburg, vol. 6, pp. 1-77.

Noopt, W.

1953. Entomostracen aus dem Litoral und dem Küstengrundwasser des Finnischen Meerbusens. Acta Zool. Fennica, no. 72, pp. 1-12.

1954a. Copepoda Harpacticoidea aus dem limnischen Mesopsmmal der Türkei. Hidrobiologi, ser. B, vol. 2, no. 1, pp. 27-40.

1954b. Die Verbreitung des Genus Parastenocaris, ein Beispiel einer subterranen Crustaceen-Gruppe. Verhandl. Deutschen Zooi. Gesellsch. Tubingen, 1954, pp. 429-435.

1955. Eine neue Parastenocaris (Copepoda Harpacticoidea) als Vertreterin limnischen Mesopsammons aus Südamerika. Arch. Hydrobiol., vol. 56 , no. 1 , pp. $76-81$.

1959. Investigaciones sôbre crustàceos subterraneos en la región neotropica. Resumes de trabajos presentados al primero Congresso Sudamericano de Zoologia, La Plata, p. 35. 


\section{$2 \mathrm{BHL}$ Biodiversity Heritage Library}

Jakobi, Hans and Loyola e Silva, Jayme de. 1962. "Two New Species of Parastenocaris (Copepoda: Harpacticoidea) from Santa Catarina, Brazil." Proceedings of the United States National Museum 113, 389-397. https://doi.org/10.5479/si.00963801.113-3458.389.

View This Item Online: $\underline{\text { https://www.biodiversitylibrary.org/item/53428 }}$

DOI: https://doi.org/10.5479/si.00963801.113-3458.389

Permalink: https://www.biodiversitylibrary.org/partpdf/193892

\section{Holding Institution}

Smithsonian Libraries

\section{Sponsored by}

Smithsonian

\section{Copyright \& Reuse}

Copyright Status: Public domain. The BHL considers that this work is no longer under copyright protection.

This document was created from content at the Biodiversity Heritage Library, the world's largest open access digital library for biodiversity literature and archives. Visit BHL at https://www.biodiversitylibrary.org. 